\title{
AKTIVITAS ANALGETIKA EKSTRAK ETANOL DAUN SUKUN (Artocapus altilis) TERHADAP MENCIT PUTIH JANTAN YANG DIINDUKSI ASAM ASETAT
}

\section{ANALGETIC ACTIVITIES OF BREADFRUIT (Artocarpus altilis) \\ ETHANOL EXTRACT TO WHITE MALE MICE INDUCED BY ACETIC ACID}

\author{
Deni Firmansyah ${ }^{*}$, Adelisa Mulyani, Delia Dwitiyani \\ Sekolah Tinggi Farmasi Muhammadiyah Cirebon \\ Jl Cideng Indah no 3 Cirebon
}

Submitted : 2 April 2019

Reviewed : 17 April 2019

Accepted: 12 September 2019

\begin{abstract}
ABSTRAK
Daun sukun memiliki khasiat analgetik karena diketahui memiliki kandungan flavonoid yang dapat bekerja sebagai analgetik dengan menghambat kerja enzim siklooksigenase. Penelitian ini bertujuan untuk mengetahui efek anaklegtik dari ekstrak etanol daun sukun (Artocarpus altilis) dengan dosis $100 \mathrm{mg} / \mathrm{KgBB}$ dan $200 \mathrm{mg} / \mathrm{KgBB}$ terhadap mencit putih (Mus musculus) jantan yang telah diinduksi oleh asam asetat sebagai perangsang nyeri. Pada penelitian ini ekstrak etanol daun sukun dibuat dengan metode maserasi sampai didapatkan ekstrak kental dengan rendemen $18,3 \%$. Hewan uji yang digunakan adalah mencit putih jantan sebantak 20 ekor dengan bobot $20 \mathrm{~g} \pm 10 \%$, yang dibagi menjadi 4 kelompok masingmasing kelompok 5 ekor, yaitu : kelompok I kontrol negatif (Na CMC 0,5\%), kelompok II kontrol positif (metampiron) dan kelompok III dan IV perlakuan ekstrak etanol daun sukun dosis $100 \mathrm{mg} / \mathrm{KgBB}$ dan $200 \mathrm{mg} / \mathrm{KgBB}$. Sebagai perangsang nyeri di induksikan asam asetat $5 \%$. Paramater yang diamati yaitu jumlah rata-rata geliat mencit tiap 10 menit selama 60 menit. Hasil penelitian menunjukkan adanya perbedaan bermakna menurunkan jumlah geliat antara kontrol positif, ekstrak etanol $100 \mathrm{mg} / \mathrm{KgBB}$ dan $200 \mathrm{mg} / \mathrm{Kg}$ BB dengan kontrol negatif $(\mathrm{p}<0,05)$ dan tidak ada perbedaan bermakna antara kontrol positif dengan ekstrak etanol $100 \mathrm{mg} / \mathrm{Kg} \mathrm{BB}$ dan $200 \mathrm{mg} / \mathrm{Kg} \mathrm{BB}$ (p>0,05). Prosentase daya analgetik metampiron $(70,42 \%)$ lebih besar dibandingkan prosentase daya analgetik ekstrak etanol dosis 100 $\mathrm{mg} / \mathrm{KgBB}(62,62 \%)$ dan dosis $200 \mathrm{mg} / \mathrm{KgBB}(64,59 \%)$. Kesimpulannya ekstrak etanol daun sukun dosis $100 \mathrm{mg} / \mathrm{KgBB}$ dan $200 \mathrm{mg} / \mathrm{KgBB}$ memilik efek analgetik tetapi prosentase daya analgetiknya masih lebih rendah dari metampiron.
\end{abstract}

Kata Kunci : Analgetik, daun sukun, metapiron, mencit putih

\begin{abstract}
Breadfruit leaves have analgesic properties because they are known to contain flavonoids which can work as analgesics by inhibiting the work of the cyclooxygenase enzyme. The aim of this study was to determine the effect of ethanol extract of breadfruit leaves (Artocarpus altilis) at a dose of $100 \mathrm{mg} / \mathrm{kg}$ bw and $200 \mathrm{mg} / \mathrm{kg}$ bw on male white mice (Mus musculus) which have been induced by acetic acid as pain stimulants. In this study, breadfruit leaf ethanol extract was made by maceration method until thick extract was obtained with a yield of $18.3 \%$. Test animals used were 20 male white mice with $20 \mathrm{~g} \pm 10 \%$ weights, which were divided into 4 groups of 5 groups each, namely: group I negative control (CMC Na 0.5\%),
\end{abstract}


group II positive control (methampyrone) and group III and IV of ethanol extract of breadfruit leaves at a dose of $100 \mathrm{mg} / \mathrm{kg}$ bw and $200 \mathrm{mg} / \mathrm{kg}$ bw. As a pain reliever, induce acetic acid 5\% (Siegmund method). The parameters observed were the average number of mice stretching every 10 minutes for 60 minutes. The results showed a significant difference in reducing the amount of stretching between positive control, ethanol extract $100 \mathrm{mg} / \mathrm{kg}$ bw and $200 \mathrm{mg} / \mathrm{kg}$ bw with negative control $(\mathrm{p}<0.05)$ and there was no significant difference between positive control and ethanol extract $100 \mathrm{mg} / \mathrm{kg}$ bw and $200 \mathrm{mg} / \mathrm{kg}$ bw (p>0.05). The percentage of methampyrone analgesic power $(70.42 \%)$ is greater than the percentage of analgesic power of ethanol extract at a dose of $100 \mathrm{mg} / \mathrm{kg}$ bw (62.62\%) and a dose of 200 $\mathrm{mg} / \mathrm{kg}$ bw (64.59\%). In conclusion, ethanol extract of breadfruit leaves at a dose of 100 $\mathrm{mg} / \mathrm{kg}$ bw and $200 \mathrm{mg} / \mathrm{kg}$ bw has analgesic effect but the percentage of analgesic power is still lower than methampyrone.

Keywords : Analgetic, breadfruits leaves, methamyrone,

\section{Penulis korespondensi:}

Deni Firmansyah

Sekolah Tinggi Farmasi Muhammadiyah Cirebon

Jl Cideng Indah no 3 Cirebon

Email :deni_king3@yahoo.com / 081322992202

\section{PENDAHULUAN}

Rasa sakit atau nyeri merupakan pertanda ada bagian tubuh yang bermasalah. Rasa nyeri timbul karena adanya rangsangan mekanis ataupun kimiawi, yang dapat menimbulkan kerusakan pada jaringan dan melepas zat-zat tertentu yang disebut mediator (perantara) nyeri seperti bradikinin, histamin, serotonin dan prostaglandin (Afrianti et al. 2014).

Sukun (Artocarpus altilis) merupakan tumbuhan dari famili Moraceae yag banyak terdapat di kawasan tropika sepeti Indonesia dan Malaysia. Salah satu bagian tanaman sukun yaitu daunnya memiliki kadungan senyawa yang berkhasiat baik untuk pengobatan, seperti saponin, asam hidrosianat. Asetilkolin, tanin, riboflavin, fenol dan flavonoid (Wuri et. al. 2011). Khasiat daun sukun berdasarkan penggunaan tradisional dan berbagai penelitian ilmiah digunakan untuk mengobati berbagai macam penyakit seperti hipertensi, sirosis hati, diabetes, hiperkolesterolemia, dan juga sebagai antiinflamasi seperti radang sendi, nyeri, gastritis dan stroke (Fakhrudin, et.al., 2015).

Flavonoid merupakan senyawa yang dapat melindungi membran lipid dari kerusakan dan menghambat enzim cyclooxygenase yang merupakan jalur pertama sintesis mediator nyeri seperti prostaglandin. Rasa nyeri akan berkurang dengan terhambatnya produksi prostaglandin oleh asam arakidonat (Mikaili et al. 2012, Afrianti et al. 2014).

Bakarbessy et.al. (2016) melakukan uji analgesik ekstrak etanol daun sukun (Artocarpus altilis) pada tikus putih galur wistar dengan hasil menunjukkan bahwa ekstrak etanol daun sukun (Artocarpus altilis) dosis $0,9 \mathrm{~g} / \mathrm{KgBB} ; 0,38 \mathrm{~g} / \mathrm{KgBB} ; 0,76 \mathrm{~g} / \mathrm{KgBB}$ mampu memberikan efek analgesik pada dosis tersebut. Penelitian Ajah A.A., et.al., (2016), menunjukkan juga bahwa ekstrak etanol daun sukun pada dosis $100 \mathrm{mg} / \mathrm{KgBB} ; 200$ $\mathrm{mg} / \mathrm{KgBB}$; dan $300 \mathrm{mg} / \mathrm{KgBB}$ mampu memberikan efek analgetik pada tikus galur wistar.

Proses ekstraksi dan fraksinasi dengan pelarut organik yang berbeda tingkat kepolaran akan mempengaruhi jenis dan kadar senyawa bioaktif serta aktivitasnya (Sousa $e t$ al. 2008). Pemilihan pelarut pada proses ekstraksi dilakukan dengan alasan karena pelarut mampu melarutkan senyawa yang akan di ekstrak, mudah dipisahkan (menguap) dan 
dimurnikan kembali (Widyawati, 2010). Menurut Hoa et al. (2007) bahwa pelarut organik digunakan didasarkan pada sifat kepolaran, kelarutan dan transfer massa dari senyawa yang di ekstrak. Kelarutan senyawa sangat ditentukan oleh kepolaran, momen dipol, polarisabilitas dan ikatan hidrogen (Martins et al. 2001).

Penelitian ini dilakukan untuk mengetahui efek analgetika ekatrak etanol daun sukun (Artocarpus altilis) terhadap mencit putih jantan (Mus musculus) jantan yang telah diinduksi asam asetat dengan mengamati jumlah geliat mencit.

\section{METODE PENELITIAN}

\section{Bahan}

Bahan yang digunakan adalah, daun sukun (Artocarpus altilis), metampiron injeksi (Novalgin, Aventis), aquadest, etanol 70\%, asam asetat 36\%, Na CMC, mencit putih jantan.

\section{Prosedur Penelitian}

1. Persiapan hewan uji

Hewan uji yang digunakan adalah mencit putih jantan dalam keadaan sehat, dengan bobot \pm 20 gram sebanyak 20 ekor. Mencit dikelompokkan menjadi 4 kelompok. Kelompok kontol negatif (suspensi Na CMC), kontrol positif (Metampiron), ekstrak etanol daun sukun dosis $100 \mathrm{mg} / \mathrm{Kg} \mathrm{BB}$ dan $200 \mathrm{mg} / \mathrm{Kg} \mathrm{BB}$.

2. Pembuatan ekstrak etanol daun sukun

Simplisia daun sukun sebanyak 500 gram di ekstraksi dengan cara maserasi menggunakan etanol 70\%, ekstrak etanol yang didapatkan kemudian dipekatkan dengan menggunakan vacuum rotary evaporator dan penguapan pelarut dengan menggunakan waterbath sampai mendapat ekstrak kental, menghitung rendemen hasil ekstraksi.

3. Perlakuan hewan uji

Mencit yang telah ditimbang dikelompokkan menjadi 4 kelompok, tiap kelompok terdiri dari 5 ekor mencit. Kelompok I kontrol positif (metampiron), kelompok II kontrol negatif (Na CMC), kelompok III ekstrak etanol daun Sukun dosis 100 mg/Kg BB (EE100), dan kelompok IV ekstrak etanol daun sukun dosis $200 \mathrm{mg} / \mathrm{Kg}$ BB (EE200). Tiap kelompok perlakuan diberikan secara peroral, kelompok I (metampiron dosis 1,3 mg/20gBB), kelompok II (Na CMC), kelompok III (EE $100 \mathrm{mg} / \mathrm{KgBB}$ ), kelompok IV (EE $200 \mathrm{mg} / \mathrm{Kg}$ $\mathrm{BB})$. Setelah 5 menit pemberian masing-masing mencit diinduksi asam asetat 5\% secara intraperitonial. Amati jumlah geliat yang timbul setiap 10 menit selama 60 menit.

4. Analisis data

Data hasil penelitian yang didapat kemudian diolah, dan dianalisis menggunakan uji statistika Oneway ANOVA dengan posc hoc test LSD.

\section{HASIL DAN PEMBAHASAN}

Penelitian ini menggunakan ekstrak etanol daun sukun dengan dosis $100 \mathrm{mg} / \mathrm{KgBB}$ dan $200 \mathrm{mg} / \mathrm{Kg}$ BB. Rendemen hasil ekstraksi diperoleh sebesar 18,3\%. Daun sukun diketahui banyak memiliki kandungan flavonoid. Flavonoid dapat bekerja sebagai analgetik dengan menghambat kerja enzim siklooksigenase (Suryatno, 2013). Dengan demikian akan mengurangi produksi prostaglandin oleh asam arakidonat sehingga dapat mengurangi rasa nyeri (Gunawan et. al., 2008). 
Tabel I. Rata-rata jumlah geliat mencit masing-masing perlakuan

\begin{tabular}{lcccccc}
\hline \multirow{2}{*}{ Perlakuan } & \multicolumn{6}{c}{ Rata-rata jumlah geliat tiap 10 menit } \\
\cline { 2 - 7 } & I & II & III & IV & V & VI \\
\hline Kontrol Negatif & $6,6 \pm 3,3$ & $19,6 \pm 7,7$ & $24,8 \pm 14,4$ & $21,8 \pm 5,6$ & $20,8 \pm 9,0$ & $15 \pm 7,5$ \\
Kontrol Positif & $5,2 \pm 3,1$ & $7,8 \pm 2,2$ & $6,6 \pm 4,0$ & $5,4 \pm 3,4$ & $3,6 \pm 2,6$ & $2,6 \pm 1,9$ \\
EE 100 & $4,8 \pm 1,6$ & $8,6 \pm 1,1$ & $9 \pm 2,1$ & $9,2 \pm 2,3$ & $4,4 \pm 1,1$ & $3,6 \pm 1,5$ \\
EE 200 & $3,4 \pm 1,6$ & $7,6 \pm 1,5$ & $8,6 \pm 5,9$ & $9,2 \pm 3,1$ & $5,6 \pm 4,4$ & $2,8 \pm 2,5$ \\
& & & & & & \\
\hline
\end{tabular}

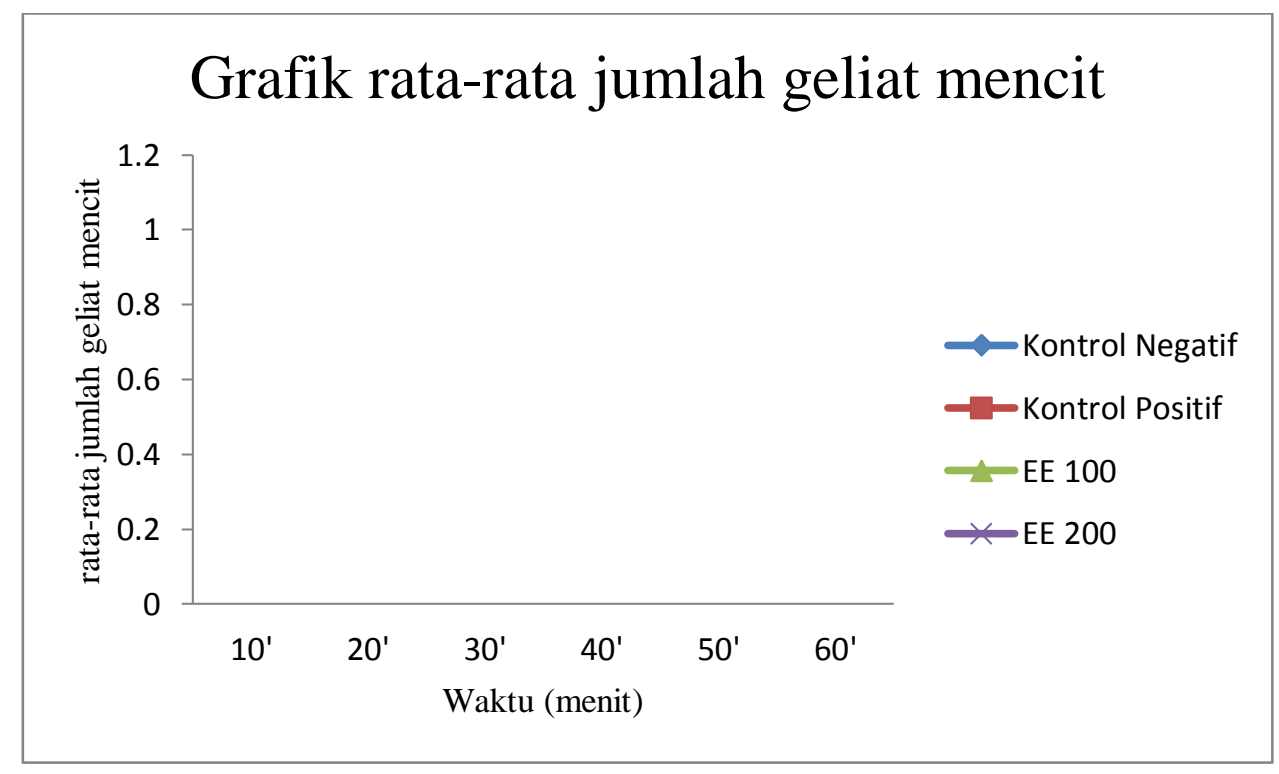

Gambar 1. Grafik rata-rata jumlah geliat mencit kontrol negatif, kontrol positif, ekstrak etanol daun sukun dosis $100 \mathrm{mg} / \mathrm{Kg}$ BB dan $200 \mathrm{mg} / \mathrm{Kg} \mathrm{BB}$.

Keterangan :

Kontrol Negatif : Na CMC 0,5\%

Kontrol Positif : Metampiron dosis 1,3 mg/20g BB

EE 100 : Ekstrak etanol daun sukun dosis $100 \mathrm{mg} / \mathrm{Kg} \mathrm{BB}$

EE 200 : Ekstrak etanol daun sukun dosis $200 \mathrm{mg} / \mathrm{Kg} \mathrm{BB}$

Pemilihan proses ekstraksi dengan cara maserasi dilakukan agar zat aktif yang terkandung dalam daun sukun tidak rusak akibat pemanasan berlebih. Pelarut yang digunakan adalah etanol $70 \%$ karena untuk menarik senyawa flavonoid yang bersifat polar dan mempunyai sejumlah gugus hidroksil, sehingga akan larut dalam pelarut polar seperti etanol, metanol, butanol, aseton dan air (Sjahid, 2008).

Penelitian ini dilakukan dengan menggunakan metode kimia (siegmund test) yang menggunakan asam asetat sebagai perangsang nyeri pada mencit yang akan diberi perlakuan. Metode yang dilakukan dengan cara melihat dan menghitung jumlah geliat (writhing) yaitu abdomen menyentuh dasar tempat berpijak dan kedua psang kaki ditarik kebelakang. Geliat 
inilah yang menjadi tolak ukur bahwa mencit mengalami rasa nyeri atau sakit (Darmono, 2011). Pada tabel 1 didapatkan jumlah rata-rata geliat untuk kontrol negatif lebih banyak dibandingkan dengan kelompok perlakuan yang lain.

Hasil penelitian menunjukkan adanya penurunan jumlah geliat pada mencit untuk kelompok perlakuan ekstrak etanol dosis $100 \mathrm{mg} / \mathrm{Kg}$ BB, $200 \mathrm{mg} / \mathrm{KgBB}$ dan kelompok kontrol positif dapat dilihat pada gambar 1. Analisis statistik menunjukkan bahwa kelompok kontrol negatif berbeda bermakna dengan kontrol positif dan perlakuan ekstrak etanol daun sukun dosis $100 \mathrm{mg} / \mathrm{Kg}$ BB dan $200 \mathrm{mg} / \mathrm{Kg}$ BB dengan nilai $\mathrm{p}<0,05$. Sedangkan untuk kelompok perlakuan yaitu ekstrak etanol daun sukun dosis $100 \mathrm{mg} / \mathrm{Kg}$ BB dan $200 \mathrm{mg} / \mathrm{Kg}$ BB menunjukkan tidak adanya perbedaan yang bermakna ( $p>0,05)$. Hal ini menunjukkan bahwa ekstrak etanol daun sukun dosis $100 \mathrm{mg} / \mathrm{Kg}$ BB dan $200 \mathrm{mg} / \mathrm{Kg}$ BB memiliki efek analgetik dengan mampu menurunkan rangsangan nyeri pada mencit yang ditimbulkan oleh asam asetat. Daun sukun juga berpotensi untuk dikembangkan sebagai bahan obat baru sebagai analgetik.

Dari gambar 1 diperoleh hasil prosentase daya analgesik dari kontrol positif sebesar $70,42 \%$; perlakuan ekstrak etanol dosis $100 \mathrm{mg} / \mathrm{Kg}$ BB sebesar 62,62\%; dan perlakuan ekstrak etanol dosis $200 \mathrm{mg} / \mathrm{Kg}$ BB sebesar $64,59 \%$. Prosentase daya analgetik kontrol positif (metampiron) masih lebih besar dibandingkan dengan prosentase daya analgetik dari ekstrak etanol daun sukun dosis $100 \mathrm{mg} / \mathrm{Kg}$ BB dan $200 \mathrm{mg} / \mathrm{Kg}$ BB. Hal ini menunjukkan bawa ekstrak etanol daun sukun dosis $100 \mathrm{mg} / \mathrm{Kg}$ BB dan $200 \mathrm{mg} / \mathrm{Kg}$ BB memiliki efek analgetik tetapi prosentase daya analgetiknya masih lebih rendah daripada prosentase daya analgetik metampiron. Dari hasil penelitian yang didapatkan terlihat bahwa tidak semua mencit menunjukkan respon yang sama walaupun dalam satu kelompok perlakuan. Hal yang menyebabkan respon yang berbeda-beda kemungkinan dipengaruhi oleh beberapa faktor baik internal maupun eksternal, seperti perbedaan spesies, genetik, seks dan umur.

\section{KESIMPULAN}

Hasil uji efek analgetik ekstrak etanol daun sukun dosis $100 \mathrm{mg} / \mathrm{Kg}$ BB dan 200 $\mathrm{mg} / \mathrm{Kg} \mathrm{BB}$ menunjukkan aktivitas efek analgetik.

\section{DAFTAR PUSTAKA}

Ajah A. A., Amah-Tariah F.S., and Iwu I.C., 2017, Anti-Nociceptive Potentials Of Methanolic Extract Of Artocarpus Altilis (Breadfruit) On Cheical Model Of Pain Study In Laboratory Rodents, Europan Journal Of Pharmaceutical And Medical Research, Vol. 4, No. 9, 734-737.

Afrianti R., Yenti R., dan Meustika D., 2014, Uji Aktivitas Analgetika Ekstrak etanol Daun Pepaya (Carica papaya L.) pada mencit putih jantan yang diinduksi asam asetat 1\%, Jurnal Farmasi Sains dan Klinis 1(1), 54-60.

Bakarbessy, W.H.A., Wullur, A.C., Lolo, W.A., 2016, Uji Efek Analgesik Ekstrak Etanol Daun Sukun (Artocarpus altilis) Pada Tikus Putih Galur Wistar (Rattus norvergius). Pharmacon Jurnal Ilmiah Farmasi, Vol. 5 No. 2, ISSN 2302-2493, 220-227.

Fakhrudin, N., Hastuti, S., Andriani, A., Widyarini, S., Nurrochmad, A., 2015, Srtudy on the Antiinflamatory Activity Of Artocarpus altilis Leaves Extract in Mice, International Journal Of Pharmacognosy and Phytochemical Research; 7(6), 1080-1085.

Gunawan, S.G., Setiabudy, R., Nafrialdi, Elysabeth, 2008. Farmakologi dan Terapi, Edisi 5, FKUI, Jakarta. 
Hoa, C.H.L. Cacacea, J.E. dan Mazza, G., (2007), "Extraction of lignans, proteins and carbohydrates from flaxseed meal with pressurized low polarity water", LWT, 40, hal 1637-1647.

Martins, M.A.P. et al. (2001), "Molecular structure of heterocycles: 6. solvent effects on the 170 NMR chemical shifts of 5-trichloromethylisoxazoles", Journal Brazil Chemical Society, 12(6), hal 804-808.

Mikaili P., Sharifi M., Sarahroodi S., dan Shayegh J., 2012, Pharmacologicalreview of medicinal trees spontaneous in Iran. A historical and modern study. Advances in Environmental Biology 6(1), 165-175.

Sjahid, L., R., 2008, Isolasi dan Identifikasi Flavonoid dari Daun Dewandaru (Eugenia uniflora L.), Skripsi, Fakultas Farmasi Universitas Muhammadiyah Surakarta.

Sousa, A. et al., (2008), "Effect of solvent and extraction temperatures on the antioxidant potential of traditional stoned table olives "alcaparras", LWT, 41, hal 739-745.

Suryatno, E. 2013, Potensi Ekstrak Fenolik Buah Pisang Goroho (Musa Spp.) Terhadap Gula Darah Tikus Putih (Rattus norvegicus), Chem. Prog., 6(1), 6-10

Widyawati P.S., Wijaya C.H., Harjosworo P.S., dan Sanjuthi D., 2010, Pengaruh Ekstraksi dan Fraksinasi terhadap kemampuan menangkap radikal bebas DPPH (1,1-Difenil-2Pikrilhidrazil) ekstrak dan fraksi daun beluntas (Pluchea indica Less.), Seminar Rekayasa Kimia dan Proses 2010, ISSN : 1411-4216.

Wuri, N., Djoko, A.B., Dwi, R.I., 2013, Uji Potensi Ekstrak Daun Sukun (Artocarpus altilis) Terhadap Lalat Rumah (Musca domestica) dengan Metode Semprot. Universitas Brawijaya 